\title{
Diagnoosin osumakohdista
}

Tervonen, Ilkka. 1981. Diagnoosin osumakohdista. Aikuiskasvatus 1, 3-4, 99-101. - Artikkelissa analysoidaan aikuiskasvatuksen kielellisten ilmaisujen merkitystä, sivistystyön kehittymisen eri vaiheita ja aikuiskoulutuksen tehtäväaluejaon pätevyyttä vastineena edellisessa Aikuiskasvatus -lehdessä olleeseen Aulis Alasen artikkeliin. Kirjoittaja käsittelee aikuiskasvatuksen yleisen terminologian ja lähtökohtien lisäksi myös Aikuiskoulutuksen väliaikaisen kehittämisorganisaation laatimaa Aikuiskoulutuksen suunnittelukäsitteistöä kritisoiden mm. peruskäsitteitä.

Vaikka Aulis Alasen kirjoitukset molemmissa Aikuiskasvatus -lehden ilmestyneissä numeroissa ${ }^{1}$ antaisivatkin aihetta laajempaankin debattiin, keskityn tässä kuitenkin pelkistetysti niihin asioihin, joissa hän on välittömästi kritisoinut esittämieni ajatusten perusteita. ${ }^{2}$ Tästä syystä puutun ensisijaisesti kolmeen kysymykseen:

1. onko tieteellä, sivistystyöllä ja valtiollisella aikuiskoulutuspolitiikalla omat "semantiikkansa";

2. onko vapaan sivistystyön kehityksessä erotettavissa kansansivistyksen, aikuiskasvatuksen ja aikuiskoulutuksen vaiheet;

3 . onko mahdollista arvostella aikuiskoulutuskomitean esittämää aikuiskasvatuksen tehtäväalueiden nelijakoa ${ }^{3}$.

Sikäli, kun olen tulkinnut oikein, ovat lähinnä nämä seikat Alasen kritiikin kannalta fundamentaalisia.

\section{Onko kysymys vain aste-eroista?}

Perusväittämäni, jotka koskevat kielellisten merkitysten muodostumista inhimillisen käytännön eri alueilla, olivat ja ovat edelleen seuraavat:

1 . tieteellä, käytännön sivistystyöllä ja valtiollisella aikuiskoulutuspolitiikalla on omat "semantiikkansa", jotka poikkeavat toisistaan ratkaisevasti;

2 . nämä erilaiset "semantiikat"' ovat muotoutuneet kyseisten alueiden käytännön myötä ja niiden väliset erot ilmentävät kyseisten käytäntöjen erilaisuutta;

3 . vaikka mainitut "semantiikat" poikkeavat merkittävästi toisistaan, eivät ne kuitenkaan ole puhtaita, sillä muuten ei minkäänlainen kommunikaatio eri alueiden välillä olisi mahdollista.
Aulis Alanen puolestaan lähtee siitä olettamuksesta, että on olemassa "runkokäsitteistö", joka "'edustaa yhteisten merkitysten kenttää’'. Hän näkee peruseroavuuksien käsitteenmuodostuksessa johtuvan vain "tiedostamisen ja käsitteellistämisen asteesta". Näin hahmottuu se, missä olemme eri mieltä: onko kysymys vain aste-eroista vai ratkaisevasti toisistaan poikkeavista käytännön alueista?

Ymmärtääkseni Aulis Alasen konseption kriittiseksi pisteeksi kiteytyy kysymys käytännön ja käsitteenmuodostuksen keskinäissuhteesta, ts. liittyykö käytäntö merkitysten muodostumiseen vai ei. Tähän kysymykseen hän ei anna eksplisiittistä vastausta, joten on pakko tarkastella hänen konseptionsa seurauksia hypoteettisesti, niin kielteisen kuin myönteisenkin vastauksen kannalta.

Oletetaan, että vastaus on myönteinen. Tällöin Aulis Alasen konseptiosta seuraisi, ettei tieteellinen, sivistyksellinen ja valtiollinen käytäntö olennaisesti poikkea toisistaan. Tästä seuraisi esimerkiksi väite, että valtiohallinto pyrkii tieteelliseen teorianmuodostukseen tai ainakin sen suuntaan. Mielestäni tällainen väite on mieletön ja olen yrittänyt perustella kantaani lähinnä rakenteellisen tavoitteisuuden käsitteellä. Ymmärtääkseni kantaani tukee jokseenkin kaikki tieteenfilosofinen ja -teoreettinen sekä valtioteoreettinen tutkimus ${ }^{4}$.

Oletetaan toiseksi, että vastaus on kielteinen. Tämä siis tarkoittaa, että "semantiikan" muodostuminen ja käytäntö ovat olennaisesti autonomisia suhteessa toisiinsa. Tällöin käytäntöjen erilaisuus ei johda eri "semantiikoihin", vaan "yhteisten merkitysten kenttä" säilyy. Tämä pitääkin paikkansa siinä suhteessa, että tieteen, sivistystyön ja valtiohallinnon edustajat ymmärtävät määrätyt asiat samalla tavoin, esimerkiksi keskustellessaan säistä, tvohjelmista, lasten terveydentilasta ja muista arkielämän asioista. 
Ongelma ei kuitenkaan ole tässä, vaan siinä, ymmärtävätkö nämä edustajat "'ammattiroolissaan" samalla tavoin aikuiskasvatuksen "runkokäsitteistön" ja tapahtuuko tämä merkitysten muodostuminen eri käytännön alueilla samalla tavoin. Käsittääkseni nykyisen kielenfilosofian valossa tällainen väite on kestämätön: on mielenkiintoista havaita, että esimerkiksi Wittgenstein on myöhemmässä ajattelussaan varsin voimakkaasti liittänyt kielen käytäntöön ${ }^{5}$.

Näin ollen on mahdollista pelkistää Aulis Alasen esittämän konseption hypoteettiset seuraukset kahteen vaihtoehtoon, jotka mielestäni ovat molemmat kestämättömiä:

1. jos käytäntö ja merkitysten muodostuminen liittyvät toisiinsa, johtaa hänen konseptionsa siihen, ettei tarkasteltujen käytäntöjen välillä vallitse olennaisia eroja;

2. jos käytäntö ja merkitysten muodostuminen erotetaan toisistaan, johtaa hänen konseptionsa siihen, että kielen pragmaattinen aspekti eliminoidaan.

\section{Onko löydettävissä kolme vaihetta?}

Lähdin siitä, että sivistystyössä on erotettavissa kolme vaihetta sen perusteella, miltä alueelta ratkaisevat innovaatiot ovat lähteneet liikkeelle:

1. ensimmäisessä vaiheessa innovaatioiden lähteenä oli ensisijaisesti sivistystyön käytäntö, joka vaikutti ratkaisevasti niin tieteelliseen työhön kuin valtiohallintoonkin;

2. toisessa vaiheessa innovaatiot alkoivat säteillä pääasiallisesti tieteiden piiristä, joskin tämä tapahtui määrättyyn tiedekäsitykseen liittyen;

3. nyt, kolmannessa vaiheessa, on aloite siirtynyt valtiohallinnolle, josta säteilevät tärkeimmät vaikutteet.

Aulis Alasen mielestä tämä jaottelu ei "oikein osu kohdalleen". Tästä huolimatta hän itsekin myöntää, että "'parikymmentä vuotta sitten" tapahtui "niin selvä käänne, että 60luvulle uskaltaa jo nyt pystyttää kaksi historiallista vaihetta erottavan merkkipaalun"'. Edelleen hänen mielestään "aikuiskasvatuksen viimeaikaisen kehityksen yhtenä keskeisenä piirteenä on ollut valtiollistuminen siinä merkityksessä, että valtiovalta on pyrkinyt järjestelmällisesti kehittämään aikuiskoulutuspolitiikkaa osana yleistä koulutuspolitiikkaa".

Ts. Aulis Alanen itsekin tulee päätyneeksi kolmijakoon, jonka taitekohdat ja osin sisällötkin ovat samat kuin mitä olen esittänyt. Täl- tä osin en siis näe ehdotonta antagonismia käsitystemme välillä; päinvastoin, ne ovat hyvinkin saman suuntaiset. Alasen kritiikki koskee lähinnä sitä, ettei 60 -lukua voida pitää erityisenä tieteellistymisen vaiheena. Tästä olen osin hänen kanssaan samaa mieltä mutta sillä varauksella, että häneltä on jäänyt huomaamatta missä mielessä puhun tieteellistymisestä.

Luulen, että "'jo pikainen katsaus historiaan osoittaa" myös sen, mitä sanoin: tieteellistymistä tapahtui siinä mielessä, että kehityksen myötä alan tutkimuksen "opillinen" luonne väistyi. Edelleen tämä tapahtui hyvin määrätyssä muodossa, joka suuntautui spekulatiivisfilosofista tiedekäsitystä vastaan, eli kuten Antti Eskola kirjoittaa: "'Etenkin faktorianalyysista tuli suomalaiseen sosiologiaan maaginen, koneellisesti ja hygienisesti, käden ja aivon koskematta abstraktia teoriaa luova väline'" ${ }^{6}$ Mielestäni tämä pitää osin paikkansa myös aikuiskasvatukseen.

Juuri tästä syystä tutkimus mielestäni taipuikin niin joustavasti palvelemaan erilaisina "selvityksinä" valtiohallintoa. Näin se ikään kuin pohjusti ja legitimoi valtiohallinnon pyrkimyksiä. Tästä syystä onkin puhuttava varauksellisesti tieteellistymisen vaiheesta, sillä se ei johtanut sellaiseen teorianmuodostukseen ja metodiseen kehitykseen, jonka pohjalta aikuiskasvatus tieteenä olisi voinut reflektoida suhteensa niin sivistyskäytäntöön kuin valtiohallintoonkin. Tiivistäen voidaan siis sanoa: tieteellistymisen vaiheesta voidaan todellakin puhua vain suurin varauksin.

\section{Onko nelijako pätevä?}

Edellisessä artikkelissaan Aulis Alanen käsitteli aikuiskoulutuksen tehtäväalueluokitusta ja sivusi siinä kriittisesti asiasta esittämiäni käsityksiä. Esitin, että kyseinen jaottelu perustuu erilaisiin yhteismitattomiin kriteereihin. Suorittamansa tarkastelun perusteella Alanen tekee sen kokoavan päätelmän, että ' käsitellyissä luokituksissa tehtäväalueiden erottelu pohjautuu niihin aikuisten elämäntoimintojen keskeisiin osa-alueisiin, lyhyesti elämänalueisiin, joiden mukaan heidän opintotavoitteensa eriytyvät ja niitä vastaavat opinto-ohjelmat koostuvat', En kuitenkaan näe, että tämä Alasen nyt jälkikäteen kehittelemä uusi lähtökohta mitätöisi arvosteluni.

Jos oletetaan kuitenkin Aulis Alasen perusteen pätevän, ajaudutaan mielestäni kahteen perustavaan heikkouteen: 
1. Jaottelu elämänalueisiin on erittäin pinnallinen, ihmisen elämäntilanteeseen liittyvä yhteiskunnallinen kriteeri. Se jäsentää huonosti niitä funktionaalisia piirteitä elämäntilanteessa, joihin myös sivistystyö liittyy.

2. Kyseinen kriteeri ei ole sivistyksellinen, päinvastoin. Se kertoo kömpelössä muodossa vain sen, miten sivistyksellinen toiminta voi palvella joitain sen kannalta osin ulkoisia hyötynäkökohtia.

Näillä perusteilla en voi päätyä muuhun kuin siihen päätelmään, että kyseinen jaottelu ei perustu sen paremmin eriteltyyn yhteiskunnalliseen kuin sivistykselliseenkään näkemykseen. Lähinnä on kysymys vain hallinnon tarpeista jäsentää sivistystyötä omista intressilähtökohdistaan.

\section{Kummallinen rintamasuunta}

En tällaisen vastineen muodossa lähde lähemmin ruotimaan muita asioita, joihin Aulis Alasen kahdessa artikkelissa tekisi mieli puuttua. Sen sijaan en malta olla ihmettelemättä hänen rintamasuuntaansa tässä keskustelussa. Onko todella niin, ettei Alanen löydä arvostelun sijaa, käsitteellistämisen ongelmista kiinnostuneena tutkijana, esimerkiksi Aikuiskoulutuksen väliaikaisen kehittämisorganisaation johtoryhmän käsitemäärittelypaperista. ${ }^{7}$.

Määritelläänhän siinä mm. "aikuinen" seuraavasti: "Aikuisella tarkoitetaan henkilöä, joka on suorittanut oppivelvollisuuden tai sivuuttanut oppivelvollisuusiän, joka ei voi käyttää koulujärjestelmän palveluksia ja jonka koulutuksen suunnittelun kannalta on merkittävää hänen asemansa yhteiskunnassa sekä työ- ja perheyhteisössä." Seuraahan tästä määritelmästä, ettei esimerkiksi iltalukiota käyvä täysi-ikäinen ole aikuinen. Edelleen mikä on suunnittelun kannalta "merkittävä" asema yhteiskunnassa sekä työ- ja perheyhteisössä?

Tai sitten "'aikuiskoulutus": "Aikuiskoulutuksella tarkoitetaan niitä erilaatuisia organisatorisia järjestelyjä, jotka ovat tarpeen aikuisten opetuksen ja opiskelun toteuttamiseksi." Onko siis aikuiskoulutus pelkkää organisatorista toimintaa? Mitä mahdollisesti tarkoittaa näiden toimien "erilaatuisuus"?

Uskoisi, että aikuiskasvatuksen piirissä työskentelevät tutkijat olisivat kiinnostuneempia näistä määritelmistä, jotka kaikessa käsittämättömyydessään ovat kuitenkin ilmeisesti tulossa kehittämistyön perustaksi.

\section{Viitteet:}

1. Alanen, A. Aikuiskasvatuksen tehtäväalueet. Aikuiskasvatus 1/81. Alanen, A. Vapaan sivistystyön praktisen teorian kehittämisestä. Aikuiskasvatus $2 / 81$.

2. Tervonen, I. Harrastustavoitteisuuden ongelmasta. Opistolehti 4/80. Tervonen, I. Kohti uutta keskustelutilannetta. Aikuiskasvatus 1/81.

3. Kyseessä on aikuiskoulutuskomitean esittämä jaottelu yleissivistävän pohjakoulutuksen täydentämiseen, ammatilliseen aikuiskoulutukseen, yhteiskunnalliseen koulutukseen ja harrastustavoitteiseen koulutukseen. Aikuiskoulutuskomitean II osamietintö. Komiteamietintö 1975: 28.

4. Tieteiden osalta esimerkiksi Nagel, E. The Structure of Science: Problems in the Logic of Scientific Explanation. Routledge and Kegan Paul. London 1961. Marxilaisen tieteenfilosofian ja myös valtioteorian osalta mielenkiintoisia esittelyitä sisältyy teokseen Vranicki, P. Geschichte des Marxismus: Zweiter Band. Rowohlt. Frankfurt am Main 1974.

5. Tätä piirrettä Wittgensteinin myöhäisemmässä filosofiassa korostaa esimerkiksi von Wright. Hänen mukaansa Wittgensteinin ', filosofinen vakaumus oli, että ihmisyksilön elämä ja näin ollen myös kulttuurin kaikki yksilölliset ilmaisut ovat syvästi ankkuroituneet luonteeltaan sosiaalisiin perusrakenteisiin. Kysymyksessä olevat rakenteet ovat sitä, mitä Wittgenstein kutsuu '’elämänmuodoiksi"' (saks. Lebensformen) ja niiden ilmentymiä ovat "kielipelit", (saks. Sprachspiele)." von Wright, G. H. Wittgenstein suhteessa aikaansa. Teoksessa Wittgenstein L. Yleisiä huomautuksia. WSOY. Porvoo 1979.

6. Eskola, A. Yhteiskuntatieteellinen kirjallisuus yhteiskunnan heijasta. Teoksessa Eskola, A ja Eskola K (toim). Kirjallisuus Suomessa. Tammi. Helsinki 1974.

7. Aikuiskoulutuksen johtoryhmä (TT/hm). Aikuiskoulutuksen suunnittelukäsitteistö. Helsinki 1981. 